\title{
THE RISKS OF NONSTRUCTURAL BUILDING COMPONENTS IN THE CONTEXT OF EARTHQUAKE AND PEDESTRIANISED STREETS IN HISTORIC CITY CENTERS: ISTANBUL BEYOGLU CEZAYIR STREET CASE
}

\author{
İlke CİRITCI \\ İstanbul Gelişim University, Turkey \\ iciritci@gelisim.edu.tr \\ https://orcid.org/0000-0002-1492-0727 \\ Gül YÜCEL \\ İstanbul GeliŞim University, Turkey \\ gyucel@gelisim.edu.tr \\ https://orcid.org/0000-0003-3722-6479
}

\begin{tabular}{|c|l|l|}
\hline \multirow{4}{*}{ Atıf } & Ciritci, İ. ve Yücel, G. (2021). THE RISKS OF NONSTRUCTURAL BUILDING \\
& $\begin{array}{l}\text { COMPONENTS IN THE CONTEXT OF EARTHQUAKE AND PEDESTRIANISED } \\
\text { STREETS IN HISTORIC CITY CENTERS: ISTANBUL BEYOGLU CEZAYIR STREET } \\
\text { CASE. The Turkish Online Journal of Design Art and Communication, 11 (2), 541-554. }\end{array}$ \\
\hline
\end{tabular}

\begin{abstract}
In most of historical cities, some streets have been pedestrianised in order to facilitate pedestrian circulation. This situation affects functions of historical buildings and increases also pedestrian density of streets. Many historical cities in the world are threatened by earthquake. It is important to consider earthquake related disasters for the pedestrianization practices in historical cities. The historical urban centers, most of have masonry buildings, may not perform well enough to overcome the risks. Building structural system, construction date, number of storey, maintenance and repair conditions and physical changes due to functional changes are similar factors affecting the performance of the building earthquakes. Although buildings have performed sufficiently structurally against earthquakes, nonstructural components damages may occur. In case of earthquake, poor performance of nonstructural components may cause loss of function, economic losses and especially loss of life and injury. The nonstructural components of building such as parapet, roof, chimney, eave, canopy and windows are considered as risk factors that may cause injuries during earthquake. In this study, nonstructural building components that may occur possibility of injury are discussed and brought forward proposals for pedestrianised streets safety located in Cezayir Street, Istanbul. The main factors affecting the choice of Cezayir Street are; its close location to the most important cultural center of Istanbul; Istiklal Avenue, being a renovated area and the intensive street usage. The nonstructural building components of historical building in the Cezayir Street were evaluated using data obtained on-site observation of building façade as parapets, ornaments, eaves, chimneys, windows and canopies. According to the research result, it can be said that the façade glazing which is located at mostly additional flats on the buildings may lead to risk during earthquake.
\end{abstract}

Keywords: Earthquake, Historical City, Nonstructural Components, Pedestrian Street, Istanbul Cezayir Street 


\title{
DEPREM VE TARIHII ŞEHİR MERKEZLERINDEKI YAYALASTIRILMIS SOKAKLARDA YAPISAL OLMAYAN BINA BIILEŞEN RISKLERİ: İSTANBUL BEYOĞLU, CEZAYİR SOKAĞI

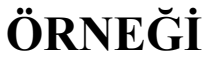

\begin{abstract}
ÖZ
Tarihi şehirlerin bir çoğunda bazı sokaklar yayaların dolaşımını kolaylaştırmak için yayalaştırılmıştır. $\mathrm{Bu}$ durum, tarihi yapıların işlevlerini etkilemekte ve caddelerin yaya yoğunluğunu da artırmaktadır. Dünyada bir çok tarihi şehir deprem gibi doğal afetler ile tehdit altındadır. Tarihi şehirlerdeki yayalaştırma uygulamaları için deprem gibi afetlerin dikkate alınması önemlidir. Çoğu kagir yapılara sahip olan tarihi kent merkezleri, risklerin üstlesinden gelmek için yeterince iyi performans gösteremeyebilir. Bina taşıyıcı sistemi, yapım tarihi, kat sayısı, bakım ve onarım koşulları ve işlevsel değişikliklere bağlı mekansal değişiklikler binaların deprem performanslarını etkileyen bazı faktörlerdir. Binalar depreme karşı yeterince yapısal performans göstermesine ragmen, yapısal olmayan bileşen hasarları meydana gelebilir. Deprem durumunda yapısal olmayan bileşenlerin zayıf performansı fonksiyon kaybına, ekonomik kayıplara ve özellikle can kaybına ve yaralanmaya neden olabilir. Binanın parapet, çatı, baca, saçak, kanopi ve pencere gibi yapısal olmayan bileşenleri deprem sırasında yaralanmalara neden olabilecek risk faktörleri olarak kabul edilmektedir. $\mathrm{Bu}$ çalışmada, yayalaştırılmış bir sokak olan İstanbul Cezayir Sokağı'nın güvenliği kapsamında, yaralanma olasılığını ortaya çıkarabilecek yapısal olmayan bileşenler tartışılmış ve öneriler getirilmiştir. Cezayir Sokağının yenileme alanı olarak seçiminde İstanbul'un en yoğun ve önemli kültür merkezi olan İstiklal Caddesi'ne yakınlığının da önemi olmuştur. Cezayir Sokağı'ndaki tarihi yapının yapısal olmayan bileşenleri, bina cephesinin parapet, süs, saçak, bacalar, pencereler ve kanopiler olarak yerinde gözlem ile elde edilen veriler kullanılarak değerlendirilmiştir. Araştırma sonucuna göre binaların üzerinde daha çok ek katlarta bulunan cephe camlarının deprem anında risk oluşturabileceği söylenebilir.
\end{abstract}

Anahtar Kelimeler: Deprem, Tarihi kent, Yapısal olmayan bileşenler, Yayalaştırılmış sokak, İstanbul Cezayir Sokă̆

\section{INTRODUCTION}

The historical city centers include the architectural cultural assets they host, as well as the natural and manmade environment surrounding it. These places contain the characteristics of traditional urban culture as well as being historical documents, as clearly stated in the International Council on Monuments and Sites - ICOMOS 1987 Regulation- (ICOMOS, 1987). In addition, historical centers are also the core of the city that include many residential, economic and cultural activities. Such settlements should not only adapt to the rest of the city but also have the ability to function as part of a larger building due to the city's growth (Mehanna, 2019). One of the decisions taken by the administrations to protect the historical areas in the cities is to open these areas to pedestrians with pedestrianization projects (Sahin \& Darby, 2014). Pedestrianization can be defined as an urban area containing one or more roads that is open to pedestrian use only, except for service traffic at certain times (Kaplan \& Acuner, 2005). Many pedestrianization projects have been implemented since the 1980s for the squares and streets that have lost their vitality and importance under vehicle traffic in Europe. The effects of pedestrianization are not limited to the region where it is applied, but it spreads to the whole city. The study investigating the effects of pedestrianization in the city of Seville, Spain has showed that the application was not limited to the region where it was made, but also contributed to the whole city (Manzano, Valpuesta, \& Flores, 2014). The majority of the people living in the city are also affected by pedestrianization practices especially in touristic areas (Akyüz \& Zengin, 2012). According to research result of the pedestrianization project around Sultanahmet Square located in the

Submit Date: 11.01.2021, Acceptance Date: 09.03.2021, DOI NO: 10.7456/11102100/014

Research Article - This article was checked by iThenticate

Copyright (C) The Turkish Online Journal of Design, Art and Communication 
Historic Peninsula of Istanbul; while users regarded the project positively in terms of safe pedestrian circulation and the presence of rest areas, the increase in the parking problem has been one of the prominent issues (Akyüz \& Zengin, 2012).

The biggest criticism of pedestrianization projects is the creation of generic spaces that look alike (Sahin \& Darby, 2014). For this reason, it is important to consider the socio-cultural structure, history and geography of the city in an integrated manner and to produce location-specific solutions. Also, pedestrianization of streets may create transportation access and parking problems (Akansel, Kaprol, \& Varl1, 2011). When access and parking problems are well identified, and the right solutions can be produced, they will contribute to the protection of cultural heritage sites in the historical core in historical cities.

The pedestrianization of street or squares are reducing traffic noise and air pollution, supporting free movement of pedestrians, the integrated use of buildings with the streets, recreational facilities and especially possibility of life in touch with the historical city. The practices, which started with the pedestrianization of Istiklal Street in Istanbul in 1990, have been spread over a wide area by pedestrianization for a certain period of time, by closing the traffic for more than two hundred streets in the Historic Peninsula. In addition to this, there are examples such as Nevizade Street, Asmali Mescit Street, Kumkap1 Meyhane Street, which are opened for long-term food and drink use in historical centers of Istanbul (Fig.1). Many of the buildings surrounding the pedestrianised streets have poor weak physical conditions for earthquake. In the pedestrianization process, it is important for pedestrian safety to examine the buildings on the street closely.

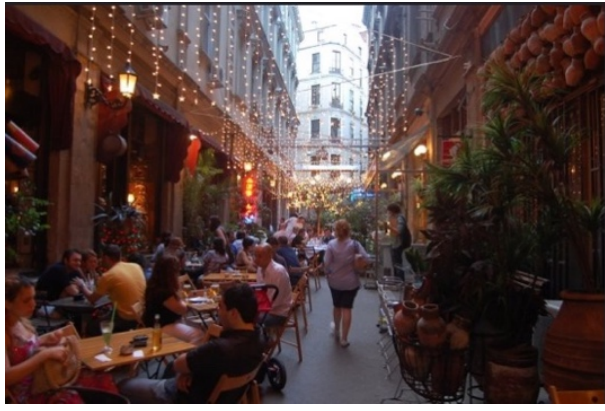

Beyoğlu, Asmalımescit (Flickr,2020)

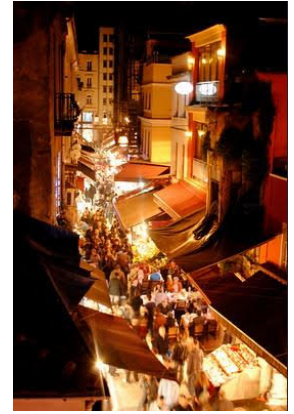

Beyoğlu, Nevizade

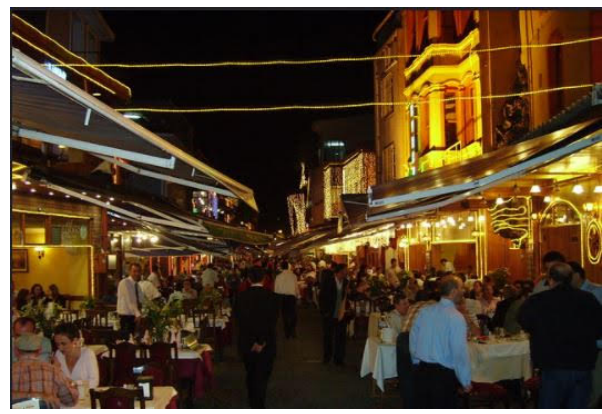

Fatih, Kumkapı (Flickr,2020)

Fig. 1 - Pedestrianised street samples, used as restaurant areas in historical center of Istanbul

Many historical cities in the world are threatened by natural hazards as earthquake. It is important to consider earthquake related disasters for the pedestrianization practices in historical cities. The historical urban centers, most of have masonry buildings, may not perform well enough to overcome the risks. Building structural system, construction date, number of storey, maintenance and repair conditions and physical changes due to functional changes are similar factors affecting the performance of the building earthquakes. Besides there are historical buildings have becoming resistant to earthquakes as structurally with proper restoration, there are also buildings that having not adequate maintenance and repair conditions. On the other hand, even though the buildings are not damaged structurally due to a medium-sized earthquake, nonstructural components may be damaged. Masonry buildings in historical centers are more vulnerable than reinforced concrete structures.

Research Article - This article was checked by iThenticate 


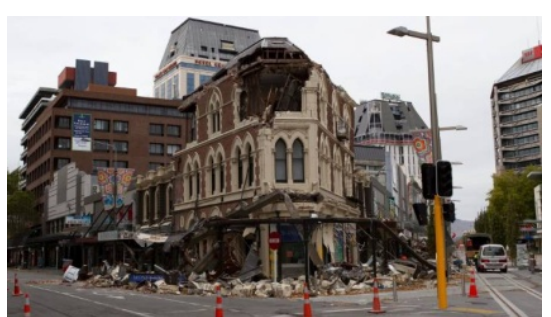

New Zealand, Christchurch

(Stuff, 2020)

22 Feb. 2011/ 6,3 Mw

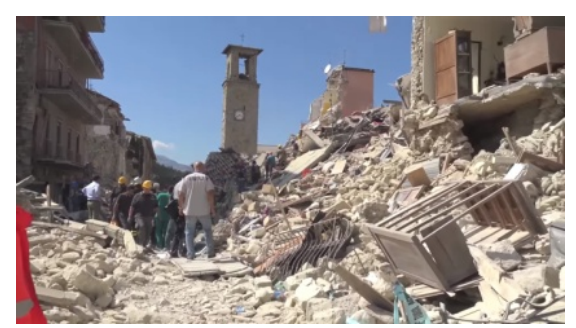

Italy, Amatrice

(Nasa, 2020)

23 Agust. 2016/ 6,2 Mw

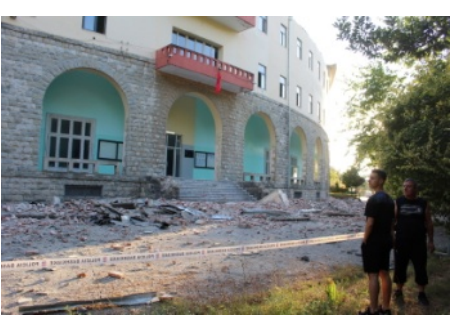

Albania (Dibra, 2019)

(Mepanews, 2019)

26 Nov. 2019 / 6,4 Mw

Fig. 2 - Earthquake effect on buildings in different country cases

The Christchurch Earthquake (February 22, 2011, 6.3 magnitude earthquake), and the Italy Amatrice (6.2 Magnitude earthquake, 23 August 2016) earthquake are important examples showing that historical city centers are physically vulnerable to a medium-sized earthquake (Fig. 2). The mediumsized earthquake in Albania is one of the current examples that reveal the importance of building architectural components such as parapets, partition wall, and glazing that fall out of the building and cause injury (Mepanews, 2019) (Fig. 2). It is important to strengthening of historical buildings at earthquake risk and to take necessary precautions in their non-structual components that may cause external injuries. Besides, taking into consideration such risks and taking precautions in pedestrianization areas in historical city centers is one of the primary issues.

Since the second half of the 20th century, many historical regions or centers have become interesting in terms of tourism and are open to visitors. In this process, the streets are opened to use with new functions for long-term use other than transportation. These streets, surrounded by historical buildings, which are particularly weak against earthquakes, pose a risk for pedestrians in terms of a mediumsized earthquake unless precautions are taken. The epidemic diseases that have increased in recent years have opened the use of open spaces in cities to discussion again. With the lifting of curfew restrictions, urbanites who need socialization have increased their interest in eating and drinking places and meeting places at open spaces in cities. Pedestrianised streets in historical areas are being used as socialization area. Although it is possible to make restoration and repair of masonry structures in historical areas, measures should be taken in a short time, especially in regions vulnerable to earthquakes, without waiting for a long process of restoration, detecting nonstructural components, which are one of the weak points of historical buildings, and quickly strengthen them with practical applications. However, in a general perspective, an examination of expert, from outside by observation can allow for the preliminary determination of the adequacy of structures in terms of maintenance and repair. The historical buildings that not restored, having large roof, canopy, console, and façade ornaments, may be affected due to the medium-sized earthquake.

Building structural system takes primary role in case of earthquake. Depending on the magnitude of the earthquake and building structural system, nonstructural building components, may cause loss of life, injury, functional loss and economic losses. Nonstructural components are grouped as architectural, mechanical and electrical components (FEMA, 2012).

Architectural components are non-bearing walls, partitions, parapets and chimneys, non-bearing wall components and connections on the exterior, veneers, suspended ceilings, raised floors, sign and advertisement signboards, architectural elements and glasses. The nonstructural components are damaged by four different ways due to earthquakes. The nonstructural components experience slipping, shaking, or tipping over due to earthquake motion (FEMA, 2012). Damage may occur to nonstructural components due to structural deformation in the building. Along different structures, nonstructural components can be damaged. Damage may occur due to the proximity and interaction of two different nonstructural components (FEMA, 2012).

Research Article - This article was checked by iThenticate 
Turkey Earthquake Building Regulations related to nonstructural building components with design principles were determined (Turkey Earthquake Building Regulations (Official Gazette of 18 March 2018, Issue: 30364 (repeated)) , 2018). In the same regulation, the building seismic design calculation is made compulsory for all kinds of console, façades and partitions, architectural components, mechanical and electrical equipment and their connections to the structural system, which are connected to the structural or the building system (Turkey Earthquake Building Regulations (Official Gazette of 18 March 2018, Issue: 30364 (repeated)) , 2018). The components such as balconies, parapets, chimneys, consoles are evaluated within the scope of all kinds of projections connected to the building structural system but working independently. Therefore, depending on the structural system performance, it can be damaged in case of earthquakes.

Although building related issues are determined within the scope of the nonstructural components specified in the regulations, additional location-specific parameters and variables also involved. For this reason, it is necessary to determine the factors that may threaten life safety on the street due to the earthquake. On the other hand, even though there is no earthquake case, there are nonstructural building component ruptures and fall risks in historical settlements depending maintenance and repair conditions. Suggestions are given different components of the nonstructural risks obtained as a result of the on-site observation.

According to recent researches, earthquake risk is high for Istanbul (IBB-JICA, 2002). Istanbul; Due to the size of its population, being a historical city, settlement characteristics and closed to the North Anatolian Fault (NAF), some of which are in the Marmara Sea, it requires working in a wide variety of areas in terms of precautions to be taken. In the National Earthquake Strategy and Action Plan Report, it is among the targets to develop technical information in order to identify and strengthen earthquake safety for the protection of historical and cultural heritage from earthquakes (AFAD, 2013). Law on the Preservation by Renovation and Utilisation by Revitalizing of Deteriorated Immovable Historical and Cultural Properties (Law No: 5366- Approval Date 16.6.2005) has led to local governments to implement interventions for renewal by putting disaster risk in the foreground. Beyoğlu Tarlabaşı Region is one of the first comprehensive renovation practices in accordance with this law. Similar risk reduction projects are carried out in many historical sites in Istanbul. Along with pedestrianization studies, determining risks, related earthquake is important for prevention studies, depending on the feature of the buildings, surrounding the street.

Although there are many nonstructural building components that can cause loss of life and injury due to earthquakes in buildings, architectural components in general include many of the components that cause external injuries. There are regulations foreseen in the new regulation for building façade components, roof, canopies, chimneys and signboard elements in relation to the building construction system, but in existing buildings and especially historical masonry buildings their compatibility with the design conditions, construction period, maintenance, repairs and due to constructional changes for reusing are uncertain. In this context, the research question is what is the status of pedestrian safety in terms of earthquakes in the streets that are pedestrianised in historical city centers? In order to investigate the answer to this question, Cezayir Street in Istanbul Beyoglu district, which was declared as a renovation area in 2006 and pedestrianised, was examined within the scope of nonstructural building components in terms of disaster risks.

\section{MATERIAL AND METHOD}

The study based on evaluation of nonstructural building components in terms of the risk of life safety outside the building in the pedestrianization areas of the city centers. The nonstructural building component risks due to the earthquake were discussed on the Cezayir Street (French Street) example in the Beyoğlu district of Istanbul in the context of pedestrianised streets with long-term use (Fig. 3). It's connection with Istiklal Avenue, important cultural axis of Istanbul, completed renovation as a

Research Article - This article was checked by iThenticate

Copyright (C) The Turkish Online Journal of Design, Art and Communication 
special project, street special features as a step street and crowd pedestrian usage are main factors for selecting as case study area.

The data are obtained from the literature search, historical and current maps related to the region and on-site observation. Physical changes of the buildings during the usage period are also taken into account in the risk assessment. The risks are identified by examining in context of nonstructural components for each building by means of on-site observation. The existence of nonstructural components risks within the scope of the earthquake are shown in the Table 1. The architectural components of the buildings are heavy masonry parapet walls, chimneys, roof tiles, large windows or glazing façade claddings. The appendages on building façade are canopy steel balustrade ornaments, signboards, heavy flowerpots, mechanical equipments (Table 1). The nonstructural building components which are related architectural and directly refer to building facades are selected in this study. The nonstructural building components which threaten street safety during earthquake were seleceted. The parameters showing in Table 1 are determined by the data obtained from on-site observation of general nonstructural components of the buildings of Beyoglu district. In the study, Turkey Building Earthquake Regulation (2018), FEMA (2012) "E-74 / Reducing the Risks of Nonstructural Earthquake Damage - A Practical Guide" are main references for identifying nonstructural parameters of building. The buildings which is located at both side of street, it's features as number of floor, structure type, additional flats and functions are shown on at plan and silhouette (Figure 5 and Figure 6). The data obtained from on-site observations are shown in Table 2 for nonstructural building components at building scale, including all buildings.

Table 1. Earthquake risk evaluation for building facades nonstructural components

\begin{tabular}{|l|l|}
\hline & Building facades and nonstructural components \\
& $\begin{array}{l}\text { Architectural (Heavy masonry parapet wall, Chimney, Roof tile, Big } \\
\text { windows /Glazing Facade cladding, }\end{array}$ \\
\hline & $\begin{array}{l}\text { Appendages on building facade (Canopy Steel balustrade Ornaments, } \\
\text { Signboard, Heavy flowerpot, Mechanical equipments) }\end{array}$ \\
\hline
\end{tabular}

\section{CASE STUDY AREA: CEZAYIR STREET}

Cezayir Street is located in Beyoğlu District of İstanbul (Fig. 3). Cezayir Street (Algeria Street) was renovated as a project named "Fransız Sokağı" (French Street) 15 years ago (Önce Vatan Gazetesi, 2016). After the project, with the pedestrian crossing on Cezayir Street, there is the density of users brought by the new function on the ground floors of the building. Along with the other five districts (Tarlabaşı District, Tophane District, Galata Tower and Surrounding, Beyoğlu Municipality Building and Surrounding, Bedrettin Neighborhood) in Beyoğlu, it has been designated as a renovation area in accordance with the law No 5366 (02/20/2006 dated, 2006/10172 no Cabinet Decree decision) (Beyoğlu Municipality, 2009). Alioğlu (2015) states in his research that housing use has changed completely as a commercial and tourism related functions with the "Fransiz Street" project (2004) of Cezayir Street. 


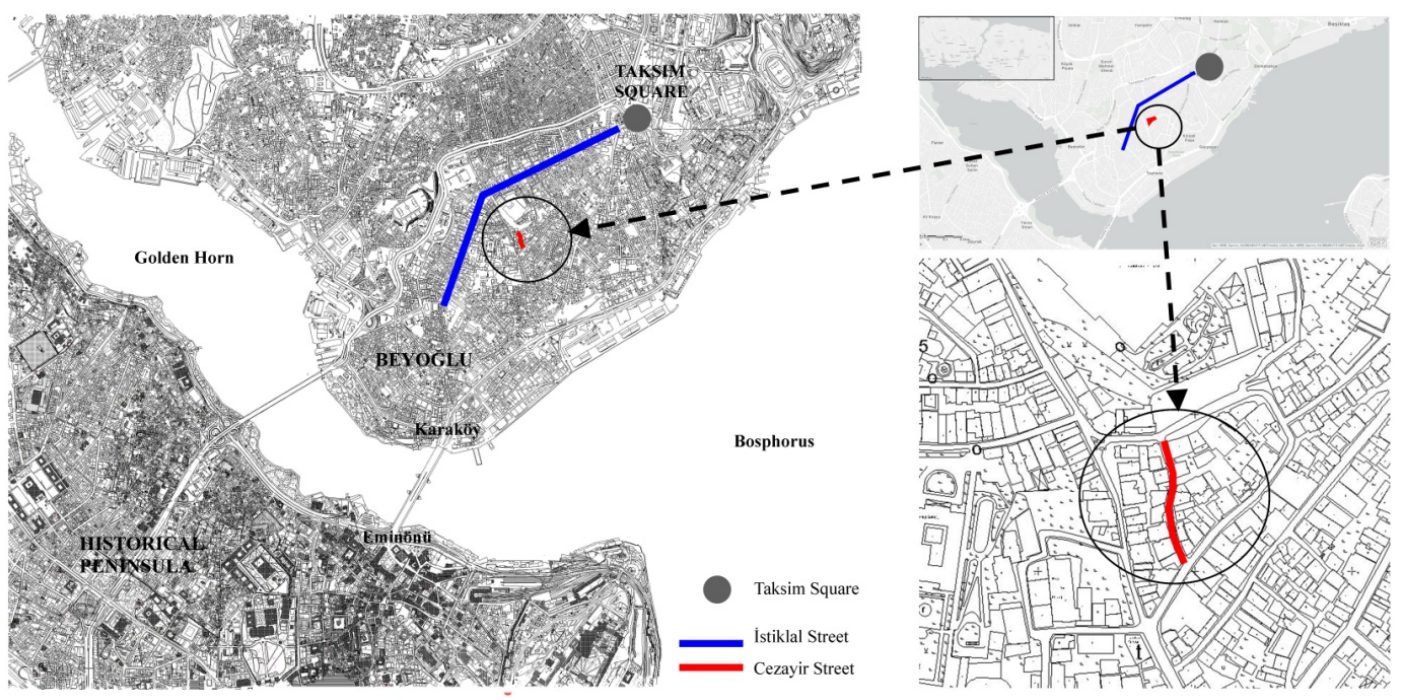

Fig. 3 - Location of Cezayir Street

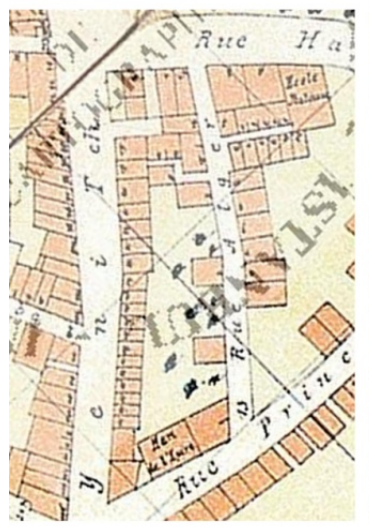

Huber, 1880

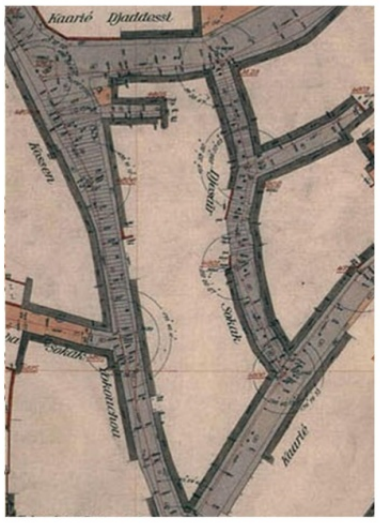

Alman Mavileri, 1915

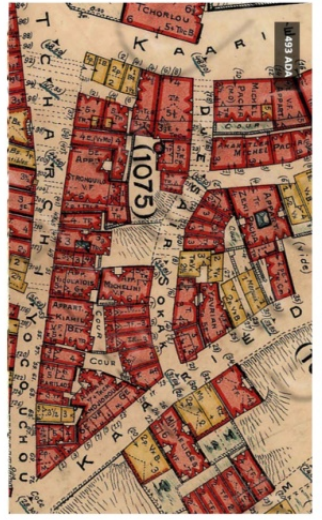

Pervititich Map,

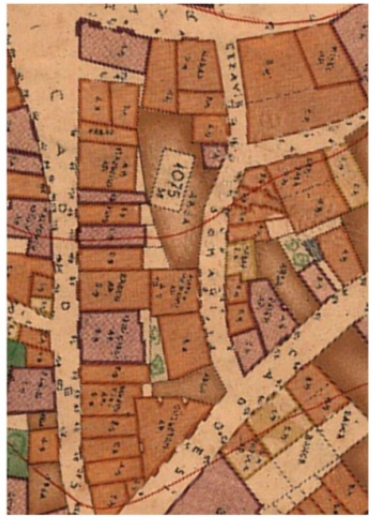

Suat Nirven Map, 1945

Fig. 4 - Historical map of Cezayir Street (IBB Atatürk Kitaplığı Harita Arşivi, IFEA Arşivi)

Turkey's first themed street project, 'French Street' project that is completed in 2004, French Street Chairman Mehmet witness whereof, connects the French monitors be seen as intense in the area of the administration of the street to the French name. Tassdiken stated that all of the buildings on the left side of the Cezayir Street had been built by the French contractor engineer Marius Michel, who also built the Karaköy and Eminönü wharves that lived in Istanbul between 1890-1910 (Hürriyet Gazetesi, 2004). In addition, the fact that the famous French painter Albert Mille lived in this region in the 1950s, the street was located behind Galatasaray High School and the establishment of the first permanent embassy of the French in this region can be shown as the reasons for the French influence in the region. The traveler Aubry Mortraye, who traveled in Galata and Beyoğlu in 1732, has defined the area where the embassy palaces are located as 'French District' (Alioğlu, 2015).

\section{FINDINGS}

\section{Street specifications: Street form, buildings, functions, using profile}

The street specifications are as physical features, building structure system, number of storey, building functions, building maintenance and repairing conditions and the nonstructural building components that threaten street safety related to the earthquake were evaluated.

Research Article - This article was checked by iThenticate 

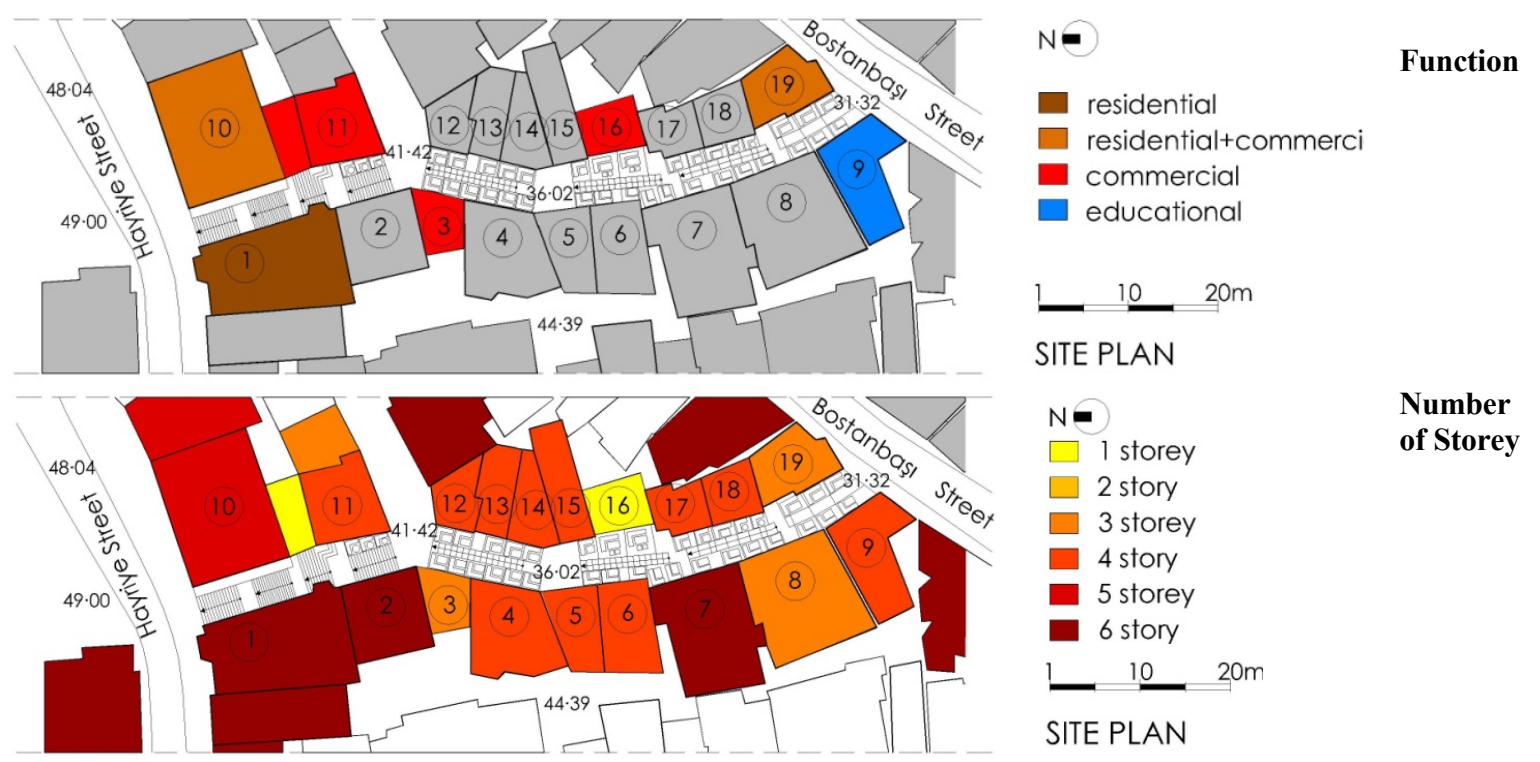

Number

of Storey

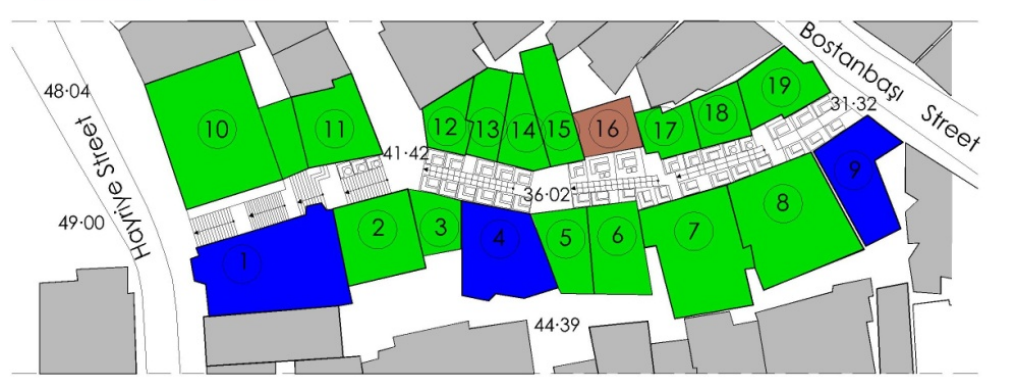

$N=$

Structure

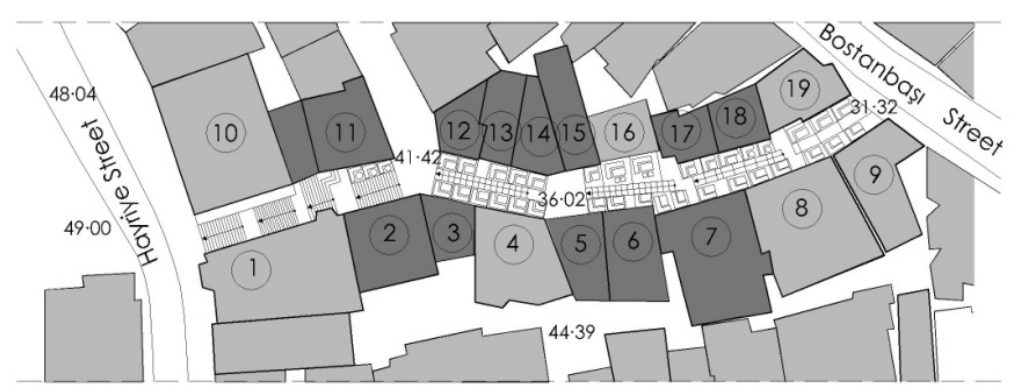

\section{SITE PLAN}

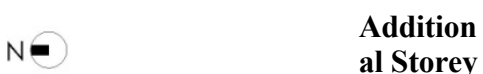

Fig. 5 - Cezayir Street building specifications (prepared by Gül Yücel)

Cezayir Street is a step street and some part of which is steep in a changing order. The form of the street with steps can also be seen on historical maps (Fig. 4). The buildings are mostly historical buildings with masonry structure. Few examples are reinforced concrete structure and are easily differs from façade layout. The ground floors of the buildings on both sides along the street are for long-term use as restaurants (Fig. 5). Ground floor of the buildings on the street is protected by canopy, sunshades within different techniques and materials, mounted on the façade (Fig 7).

Research Article - This article was checked by iThenticate 

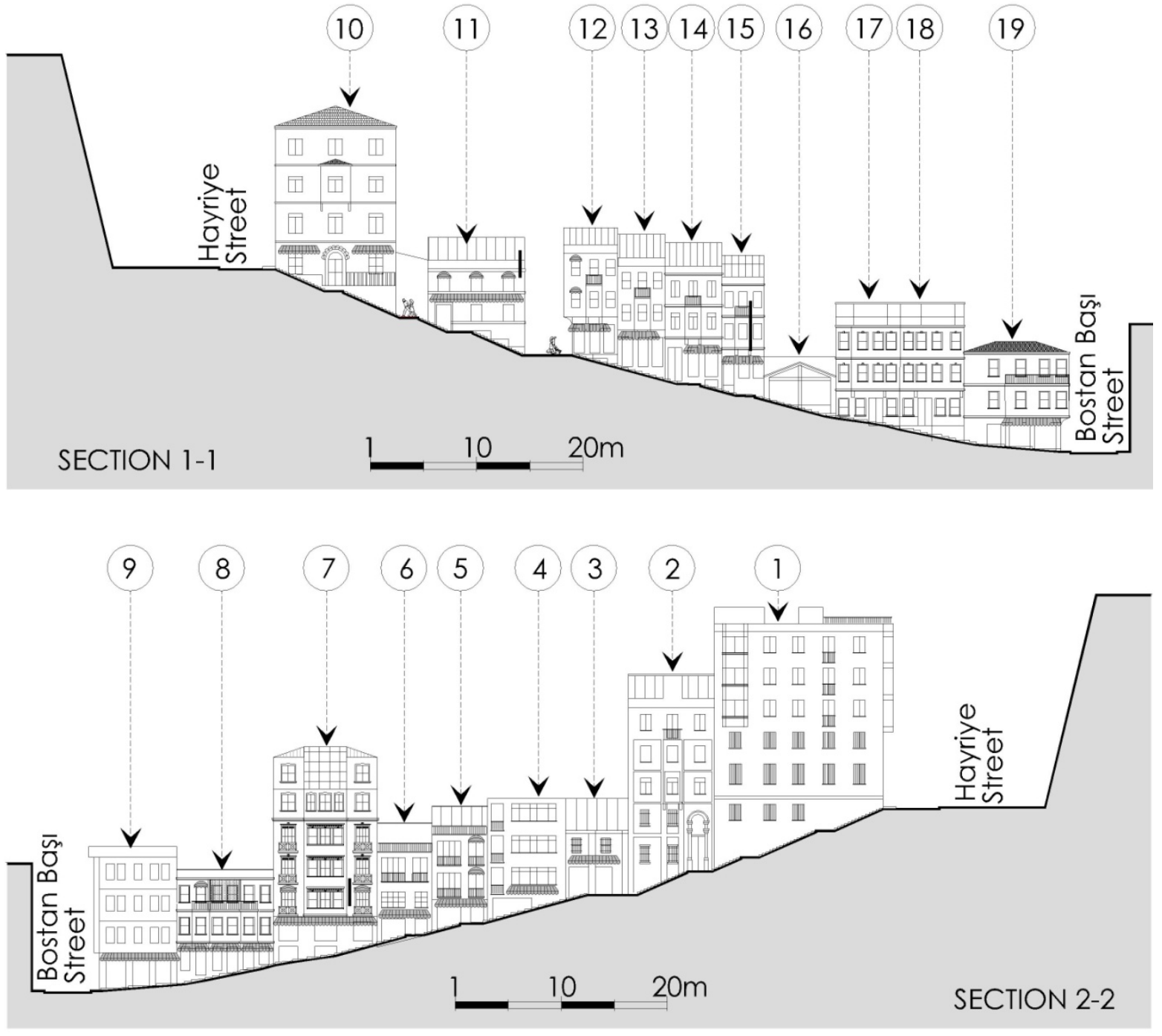

Fig. 6 - Cezayir Street siluets with each sides (prepared by Gül Yücel)

Most of the buildings in Cezayir Street, whose name turned into 'Fransiz Street' with the protection arrangements made in 2004, have functional changes. In 2004, in the French Street project, the new identity gained by the street under the chairmanship of Taşdiken targets the high-income group. With the new functions given to the buildings within the project, the residences have been transformed into famous restaurants, art galleries and French delicatessens. It has been determined that the upper floors are generally empty and not used due to the new functions of the structures whose functions are changed as well as the facade arrangements.

Research Article - This article was checked by iThenticate 

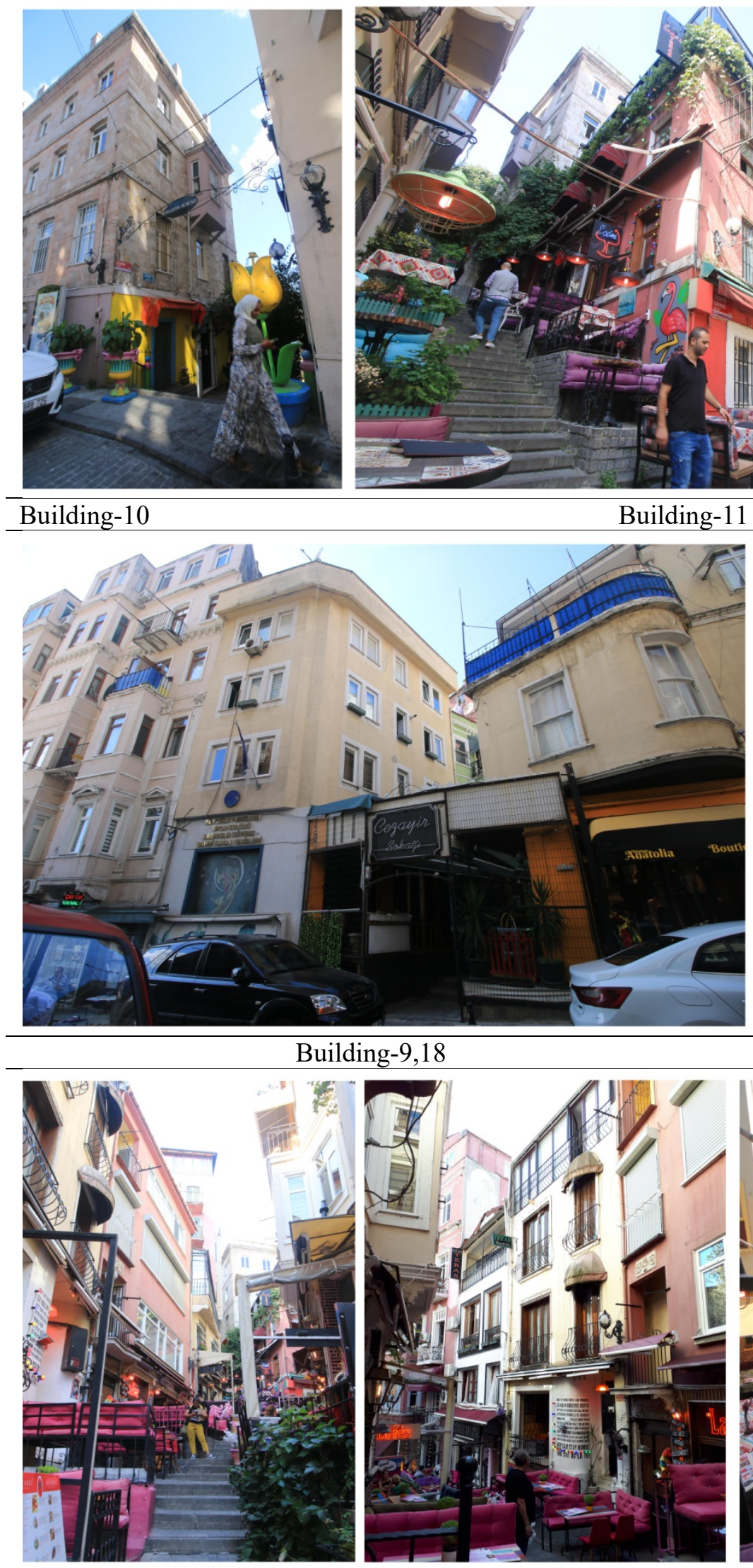

Building-4

Building-9,18

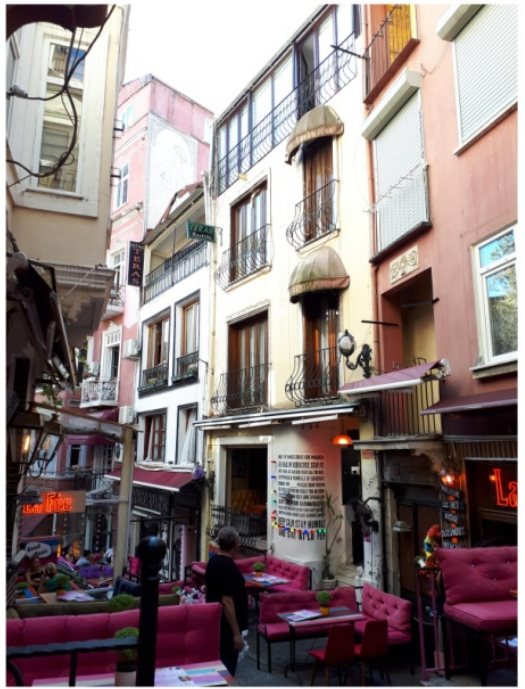

Building-5

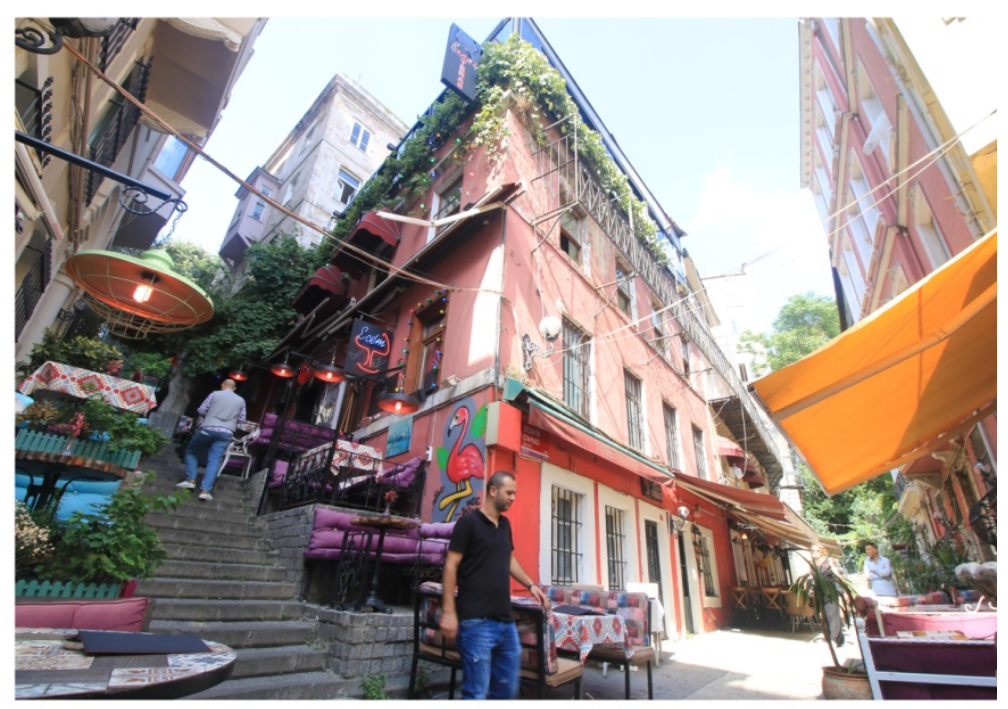

Building-11

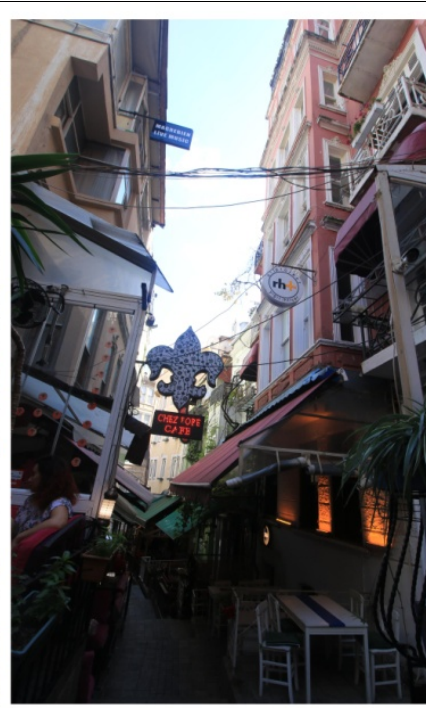

Building-7

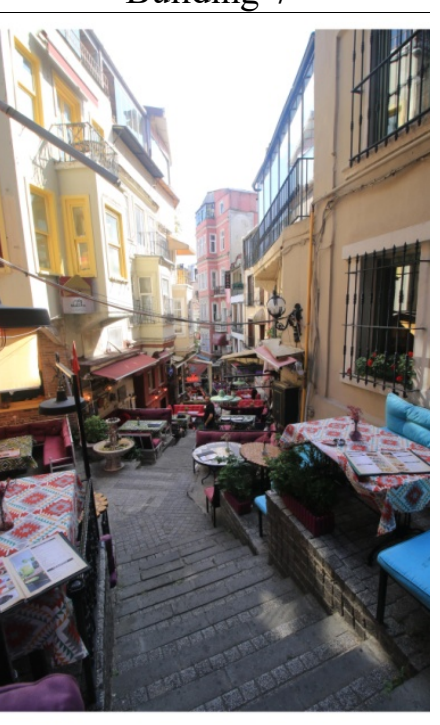

Building 3-12

Research Article - This article was checked by iThenticate 
Fig. 7 - Cezayir Street view (photo by Gül Yücel, 2019)

Terrace areas with covered glazing have been added to some of the buildings where ground floors mostly serve as cafes and restaurants, and there have been changes in the original plan types (Fig. 6, Fig. 7). With all these structural and physical changes; Cezayir Street has become one of the most visited entertainment venues in Beyoğlu district. According to Başat's (2007) study on culture, consumption and entertainment venues on Istiklal Street, Cezayir Street is one of the three regions where space uses are concentrated in this sense (Başat, 2007).

\section{Earthquake and nonstructural building component risks}

According to on-site observation, it's seen that some nonstructural components (chimney, façade cladding, steel balustrades) are not the risk factor for the Cezayir Street. To the contrary as nonstructural components, heavy masonry parapest, roof tiles, big windows, canopies, ornaments, signboards, heavy flower pots and mechanical components are determined as risk factors as seen at Table 2.

Table 2 - Nonstructural building component risks due to earthquake for Cezayir Street

\begin{tabular}{|c|c|c|c|c|c|c|c|c|c|c|c|}
\hline \multirow[b]{3}{*}{ 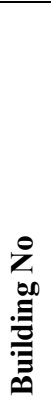 } & \multicolumn{11}{|c|}{ Building facades and nonstructural components } \\
\hline & \multicolumn{5}{|c|}{ Architectural } & \multicolumn{6}{|c|}{$\begin{array}{c}\begin{array}{c}\text { Appendages on building } \\
\text { facade }\end{array} \\
\end{array}$} \\
\hline & 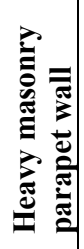 & 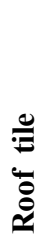 & 冚 & 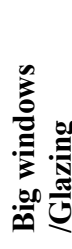 & 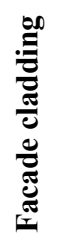 & Uे & & 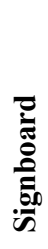 & 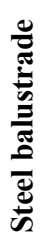 & 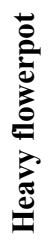 & 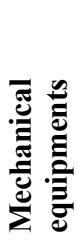 \\
\hline \multicolumn{12}{|l|}{1} \\
\hline 2 & $\mathbf{X}$ & & & $\mathbf{X}$ & & & & & & & \\
\hline 3 & & & & $\mathbf{X}$ & & $\mathbf{X}$ & & & & & \\
\hline 4 & & & & & & $\mathbf{X}$ & & & & & \\
\hline 5 & & & & $\mathbf{X}$ & & $\mathbf{X}$ & & & & & \\
\hline 6 & & & & $\mathbf{X}$ & & $\mathbf{X}$ & & & & & \\
\hline 7 & $\mathbf{X}$ & & & $\mathbf{X}$ & & $\mathbf{X}$ & $\mathbf{X}$ & & & $\mathbf{X}$ & $\mathbf{X}$ \\
\hline 8 & & & & & & $\mathbf{X}$ & & $\mathbf{X}$ & & & $\mathbf{X}$ \\
\hline 9 & & & & & & $\mathbf{X}$ & & & & $\mathbf{X}$ & \\
\hline 10 & & $\mathbf{X}$ & & & & & & & & & \\
\hline 11 & & & & $\mathbf{X}$ & & $\mathbf{X}$ & & & & & \\
\hline 12 & & & & $\mathbf{X}$ & & $\mathbf{X}$ & & & & & \\
\hline 13 & & & & $\mathbf{X}$ & & $\mathbf{X}$ & & & & & \\
\hline 14 & & & & $\mathbf{X}$ & & $\mathbf{X}$ & & & & & \\
\hline 15 & & & & $\mathbf{X}$ & & $\mathbf{X}$ & & & & & \\
\hline \multicolumn{12}{|l|}{16} \\
\hline 17 & & & & $\mathbf{X}$ & & $\mathbf{X}$ & & & & & \\
\hline 18 & & $\mathbf{X}$ & & & & $\mathbf{X}$ & & & & & \\
\hline & & & & & & & & & & & \\
\hline
\end{tabular}

According to on site observation, it can be said that the buildings have potential nonstructural component risks within the scope of the earthquake. One of these risks is some structural modification due to functional changes. With the need to create a new space, modifications made in the interior partition walls, changing existing spaces in the facade walls, and increase the number of floors. The addition storeys or terraces to historical buildings increase building risk against earthquakes in addition to the destruction of the original structure. In generally glass material usage is observed on the additional floors to the buildings. It is also observed that the air conditioning equipment is fixed to the façade wall with anchorage (Fig.7). This type of equipments may behave depending on the structure of the wall on which it is anchored. According to on-site observation, there are intensive 
landscaping at terraces of buildings and flower pots on facade or balcony parapets (Table 2). It should be taken into consideration that such appendices may also fall down and pose a risk. The street is a crowded street at any time of the day; it is mostly used for entertainment at nights and during the day for tourism and visiting purposes. Because of historical old buildings and insufficient street width, all kinds of nonstructural building components may pose risk, in terms of life safety.

It is possible to take prevention action for many of the elements considered to be risky in the structures and to reduce the potential risk in case of disaster. In Fig.7, it is seen that in most of the buildings the air conditioning unit is mounted on the main wall of the facade. This increases the risk particularly in the buildings that are older than a century, weak for heavy loads and the mortars and the connective feature has decreased and has weakened. Similarly, there are heavy iron railings on balcony or terraces, most of the buildings along the street. Most of them are not original, new constructed. These appendices are the group that poses the greatest risk in the earthquake.

Many of the buildings have glazing, rosettes, ornaments and claddings. The material of most of these elements is stone. It is possible that these types of decoration materials of these buildings which have not been maintained, repaired or restored since the day they were built, can also be displaced easily.

\section{CONCLUSION}

In the pedestrianization of the streets, earthquake disaster risks should be taken into consideration as well as the arrangement of the promenade areas, and external security of the buildings surrounding the street should be provided. The earthquake disaster risks should be taken into consideration at the streets pedestrianizations in historical centers. The architectural components of the buildings are heavy masonry parapet walls, chimneys, roof tiles, large windows or glazing façade claddings. The appendages on building façade are canopy steel balustrade ornaments, signboards, heavy flowerpots, mechanical equipments It has been determined that the highest risks encountered in Cezayir Street are, big windows and canopies. In addition to these, heavy masonry parapet walls, roof tiles, heavy flowerpots, mechanical equipments, ornaments and signboards also pose a safety problem for people because of the danger of falling, over the course of an earthquake. In order to prevent such dangers, some improvements can be recommended specifically for Cezayir Street. These suggestions can also be applied to other historical places.

- The building nonstructural components in the pedestrianised streets should be strengtened for providing street safety and protection any injuries.

- It may be proposed to move the air conditioner units to the roof or to move only the air conditioner by designing another element adjacent to the existing structure, which saperate from building structure.

- Automatic sunshades for sitting areas front of buildings should be removed from the original structure due to the high risk of detachment from the structure.

- If there is a weakness in the places where the stones meet with the wall, they should be fixed. Otherwise, in any case, these stones may break from the structure and threaten street safety.

- Connecting the stone under the plaster with carbonfiber threads or fabrics can also be counted among the methods.

- For the cornices on the facades of the buildings, the broken areas can be intervened by sewing technique.

- The cracks can be applied with the original material together with the steel clamps and epoxy used for historical stone works.

- However, in case of difficulty, for example, a fragmented element can be attached to the structure with steel interlocks with minimal intervention. However, while doing this, it is important that the clamp is seen from the outside and exposed, as well as minimum intervention on structure or material of building.

- If serious cracking and rupture is anticipated, there should be reversible interventions whenever possible within the scope of emergency protection measures. (Principles for Analysis, Conservation and Structural Restoration of Architectural Heritage, 2003, Article 3.9)

Research Article - This article was checked by iThenticate 
- Determination of the properties, type of use and density of the buildings has priority in the intervention.

- Nonstructural component issues due to earthquake are closely related to building structural system, maintenance and repair conditions. Any renovation or retrofitting to the building should be in such a way that the material difference is certain and should be visible.

- At the same time, it is important to keep the attachments on building to be removed when necessary, to plan them in a way that will not damage the structure.

- Especially in pedestrianised streets where historical masonry structures are dense, risky areas should be planned to be secured along the street. Risky areas can be taken into a light steel cage, grid. In case of falling parts from these buildings, it provides safe areas.

- Similarly constructions should also be detached from buildings.

The areas that are opened to pedestrian circulation in historical cities and following in many other city centers are practices that increase comfort in urban life. In this process, earthquake-related risks should be taken into consideration for streets whose usage type and intensity change, and measures should be planned by determining the factors threatening street safety.

Besides reuse of historical buildings with their original or appropriate reuse suggestions should also be taken into account maintain the cultural asset to the future. In this kind of pedestrianization practices, heavy physical changes and the pressure of heavy use that the whole of the building or group of buildings will create on the street affect the sustainability of the process of being able to survive by using it for historical buildings.

\section{REFERENCES}

AFAD. (2013). UDSEP Ulusal Deprem Stratejisi ve Eylem Planı 2012-2023. Ankara: T.C. Başbakanlık Afet ve Acil DurummYönetimi Başkanlığı.

Akansel, S., Kaprol, T., \& Varl1, E. (2011). Edirne Tarihi Saraçlar Caddesi Yayalaştırma Projesinin Kentsel Yaşama Katkıları. Mimarlık Dergisi 359, Mayıs-Haziran, 0-0.

Akyüz, M., \& Zengin, B. (2012). Tarihi Alanların Yayalaştırılmasının Turist Memnuniyetine Etkileri: Sultanahmet Meydanı Örneği. IJSES Uluslarası Sosyal ve Ekonomik Bilimler Dergisi 2 (2), 89-94.

Alioğlu, B. (2015). Beyoğlu, Cezayir Çıkmazı ve Çevresi Kentsel Yenileme Alanı Tarihsel Gelişim ve Koruma Önerileri . İstanbul: İstanbul Teknik Üniversitesi, Fen Bilimleri Ensitüsü, Y. Lisans Tezi.

Başat, K. (2007). Şehirlerdeki Güncel Farklılaşmalar: İstanbul-İstiklal Caddesi. İstanbul: İstanbul Teknk Üniversitesi, Fen Bilimleri Enstitüsü (Yayınlanmamış Yüksek Lisans Tezi).

Beyoğlu Municipality. (2009). Accessed: https://www.resmigazete.gov.tr/eskiler/2006/03/20060328$\underline{5 . h t m}$

Dibra, M. (2019, September 2019). Trzęsienie ziemi w Albanii. Najnowszy bilans strat. January 10, 2020 tarihinde https://fakty.interia.pl/swiat/news-trzesienie-ziemi-w-albanii-najnowszy-bilansstrat,nId,3218847 adresinden alındı

FEMA. (2012). E-74 / Reducing the Risks of Nonstructural Earthquake Damage - A Practical Guide. (Federal Emergency Management Agency) 12 15, 2019 tarihinde http://www.fema.gov/earthquakepublications/fema-e-74-reducing-risks-nonstructural-earthquake-damage adresinden alınd 1

Hürriyet Gazetesi. (2004, June 14). Bir Fransız masalı. January 15, 2020 tarihinde http://www.hurriyet.com.tr/kelebek/bir-fransiz-masali-38615411 adresinden alındı

IBB-JICA. (2002). The Study on A Disaster Prevention / Mitigation Basic Plan in Istanbul including Seismic Microzonation in the Republic of Turkey. Istanbul: İBB Istanbul Büyükşehir Belediyesi-JICA Japan International Cooperation Agency.

IBB Atatürk Kitaplığı Harita Arşivi. Accessed:

http://ataturkkitapligi.ibb.gov.tr/ataturkkitapligi/index.php?dil=tr\&p=7\&ID=6

Research Article - This article was checked by iThenticate

Copyright (C) The Turkish Online Journal of Design, Art and Communication 
ICOMOS. (1987, 10 15). Washington Tüzüğ̈̈ (1987). ICOMOS:

http://www.icomos.org.tr/Dosyalar/ICOMOSTR_tr0627604001536681570.pdf adresinden alınmıştır

IFEA (French Institute of Anatolian Studies). IFEA Map Archive. http://map-archivis.ifeaistanbul.net/s/tr/item

Kaplan, H., \& Acuner, A. (2005). Ankara' da Yayalaştırma Sorunsalı: Yaya Alanlarının Yasal Çerçeve ve Yerel Yönetimlerin Rolü Kapsamında Değerlendirilmesi. Planlama Dergisi, 2005/4, 0-0.

Law on the Preservation by Renovation and Utilisation by Revita-lizing of Deteriorated Immovable Historical and Cultural Properties. (Approval Date 16.6.2005- Law No: 5366).

Manzano, J. I., Valpuesta, L. L., \& Flores, J. P. (2014). Extending Pedestrianization Processes Outside the Old City Center; Conflict and Benefits In the Case of the City of Seville. Habitat International 44, 194-201.

Mehanna, W. A.-H. (2019). Urban Renewal For Traditional Commercial Streets at the Historical Centers of Citie. Alexandria Engineering Journal, Egypt, http://doi.org/10.1016/j.aej.2019.09.015, www.elsevier.com/locate/aej, 0-0.

Mepanews. (2019, September 26). Arnavutluk'ta son 30 yılın en şiddetli depremi yaşandl. January 15, 2020 tarihinde https://www.mepanews.com/arnavutlukta-son-30-yilin-en-siddetli-depremi-yasandi29660h.htm adresinden alındı

Önce Vatan Gazetesi. (2016). Nezahat Göçmen, Cezayir Sokağı, 5 July 2016, Accessed: https://www.oncevatan.com.tr/guncel/cezayir-sokagi-h95194.html

Principles for Analysis, Conservation and Structural Restoration of Architectural Heritage, 2003, Article 3.9 Accessed: https://www.icomos.org/charters/structures_e.pdf

Sahin, S., \& Darby, D. (2014). Tarihi Kent Merkezlerinin Yaya Eksenli Olarak Yeniden Canlandırılması: Almanya Koblenz Örneği. Mimarlık Dergisi 379, Eylül-Ekim, 0-0.

Turkey Earthquake Building Regulations (Official Gazette of 18 March 2018, Issue: 30364 (repeated)) . (2018). Ankara: Official Gazette, 18 March 2018, Issue: 30364 (Repeated). 